\title{
An Analytical Study on Difference be- tween Industrial Strategy and Enterprise Strategy
}

\author{
Zhu Yadong \\ School of Economics and Management, Hebei University of Technology, Tianjin, \\ P.R.China, 300401 \\ Email: zydchina@139.com
}

\begin{abstract}
This paper conducts an analytical study on differences between industrial strategy and enterprise strategy based on relevant theories from the perspective of research subject, research purpose, environmental factor, research methods and starting points with an aim to paving the way for better study on industrial strategy.
\end{abstract}

Keywords: Industrial strategy; enterprise strategy; difference

\section{Introduction}

Entering into the $21^{\text {st }}$ century, the economic globalization sweeping across the globe bridged the time and special gap between enterprises, which speeds up the globalization of market and thus makes enterprises worldwide increasingly integrated into a one unified market. Against this backdrop, the industrial and enterprise strategy is increasingly gaining prominence. It is often believed that there is no big difference between these two. However, in fact, much difference between them can be identified in theoretical research and in real practice. This paper conducts an analytical study on such difference on the theoretical basis of industrial economics and organization and enterprise strategic management.

\section{Industrial Strategy and Enterprise Strategy}

Enterprise strategy refers to management concept of one enterprise and its master planning for development objectives, methods and approaches so as to achieve long term steady growth in light of internal and external environment and available resources. Enterprise strategic management identifies long-term objectives for enterprises and refers to the process of allocating and arranging the strategic resources to reach those objectives.

Industrial strategy refers to the longterm policy measures taken by competent authority in charge of economic affairs in tackling major industrial problems with an aim for sustained development of local and state-level industry as a whole. To be specific, industrial strategy is the proposal and plan made by the local and state department of industrial management for guiding the sound and stable development of relevant industries based upon subjective and objective conditions through a better understanding of industrial trend and development laws.

Industry is an integrated system consisting of enterprises with common features $^{[1]}$. The whole collection of industries constitutes the national economy with any particular industry being an integral part. Industrial development refers to the whole process from emergence, 
growth to industrial evolution. Hence the development strategy can be discussed in the following three layers. First, from the macro perspective, it is an industrial development strategy at state level. It is an instructive strategy guiding the development of local and national economy. Second, from meso perspective, development strategy of one particular industry and local area is an exploration of its industrial development strategy, directions and tactics. A good case in point is the industrial planning formulated by state industrial department and industrial associations. Third, from the micro perspective, it refers to the development strategy of one particular enterprise, a strategy that identifies development objectives and allocates strategic resources so as to reach those objectives. The strategy of the upper level organization can provide guiding principles for lower level organizations, thus constitutes one of the external environment for lower level organizations to analyze. Similarly, the strategy of lower level organizations is the internal environment and element for upper level to conduct strategic analysis on. National economic development strategy provides guidance for the development directions of every industry and enterprises as they serve as an integral part of the national economy. Industrial strategy and policy sets out guiding principles for the formulation of enterprise strategy, directing the development of enterprise strategy. It is the external environment that enterprises need to take into account in conducting strategic analysis. One of the objectives of strategic management is to enhance the core competitiveness of the organization. As a basic element of the national economy, the competitiveness of enterprises determines the cutting edge and international competitiveness of one industry and one country. The strategy hierarchy is shown in the figure 1 below.

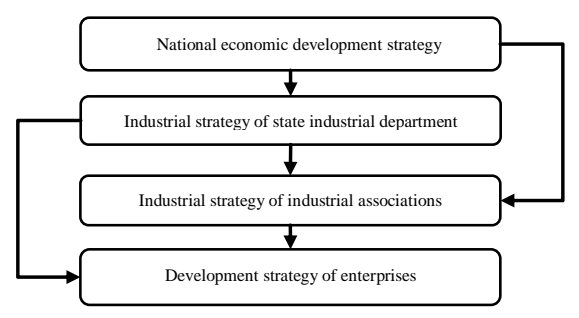

Fig. 1: Strategy Hierarchy

\section{Difference between Industrial Strategy and Enterprise Strategy}

\subsection{Difference in Research Subjects}

The research subjects of industrial strategy are government, state industrial department, and industrial associations etc. while the research subjects of enterprises are enterprises and entrepreneurs, etc.

\subsection{Difference in Research Content and Object of Study}

Industrial strategy and enterprise strategy refer to the relationship between the collectivity and the individuality in which the former matters much more than the latter combined. Enterprise strategy relates to each and every enterprise as a research individual. It advocates that each and every individual has its own unique problem with individualized competition as the analysis basis.

Industrial strategy gives more prominence to the industry with different development laws as a whole. Industrial research includes industrial organization, industrial structure, industrial correlation, industrial pattern, industrial development and industrial policy. Therefore industrial strategy must come up with a reasonable and master solution based on the industrial research of these issues.

\subsection{Difference in Research Purpose}

Such difference is determined by the roles of these two strategies in economic 
and social system. The focus of enterprise strategy lies in gaining cutting edge including the general profitability of the industry where the enterprise is located, in other words, industry attractiveness, and its comparative competitiveness as to whether it can improve itself so as to sustain long-term development in the industry.

The research purpose of industrial strategy is to gain a better understanding of changing features and laws of the industry and propose reasonable and effective solutions in order to improve competitiveness and cutting edge of core technologies. By so doing the leading position in industrial technologies can be secured.

\subsection{Different in Research Starting Point}

Enterprise strategy starts with profits and interests of enterprises themselves while industrial strategy starts with long term development of one country, one region or one industry as a whole.

\subsection{Difference in Environment}

The environmental factors of enterprise strategy include both external and internal environment. The former is usually twofold, namely macro-environment and task environment $^{[2]}$. Macro-environment usually includes many factors such as politics and law, economy, population, social culture and science and technology. Task environment includes industrial competitiveness, attractiveness and the stakeholders of enterprises. The intra-industry competition factors mainly refer to intensity of competitive rivalry, bargaining power of suppliers, bargaining power of customers, threat of substitute products or services and threat of new competition as explained in the Michael Porter's Five Forces Model ${ }^{[3]}$, which is supplemented

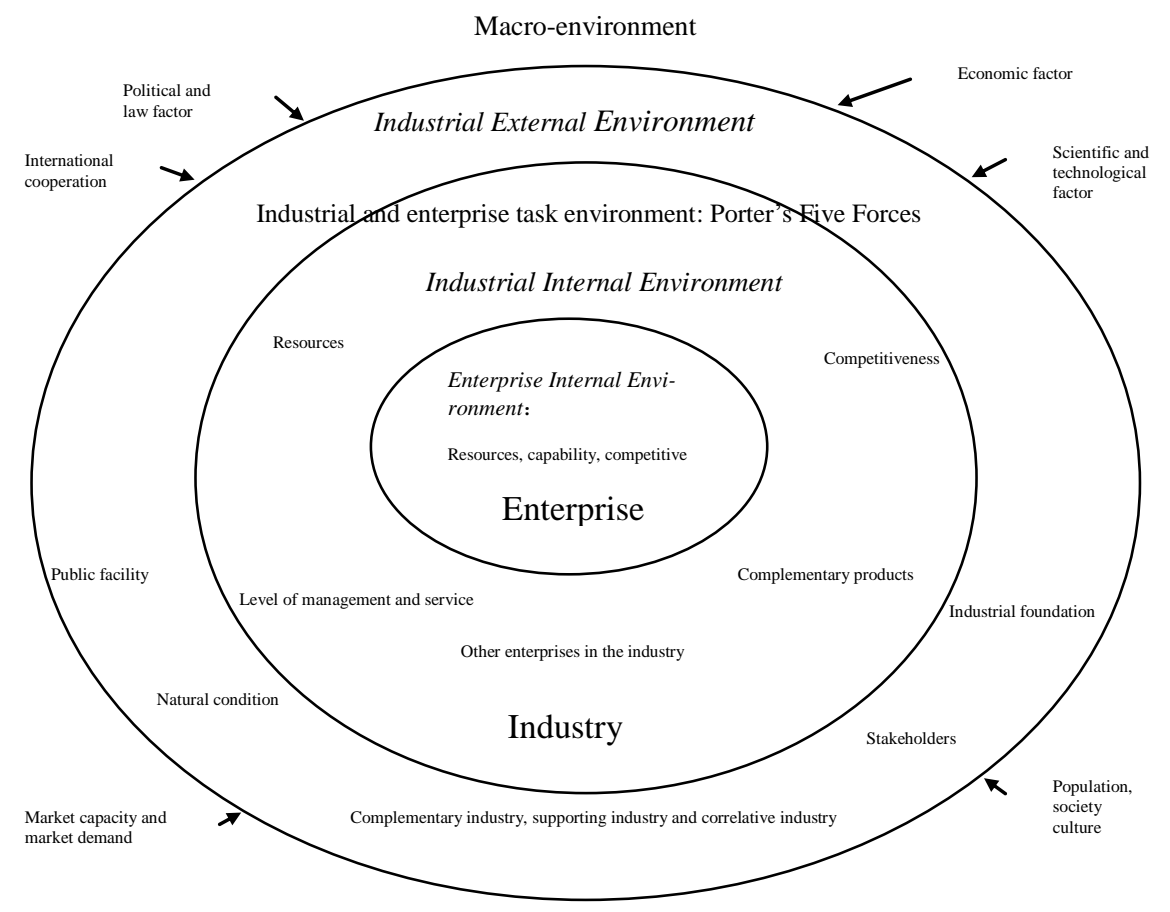

Fig. 2: Industrial and Enterprise Strategy Environment Analysis Model 
by supplementary products factors. The enterprise stakeholders include local government, local community, creditors, shareholder or partner, employees and labor union, and trade associations, etc. The internal environment includes corporate resources, capability and core competitiveness, etc.

The environment of industrial strategy also includes both external and internal environment, which exerts great influence on industry competitiveness and development. Despite similarities with enterprise strategy in external environment such as law, economy, science and culture, and in internal environment shaped by Porter's five forces, complementary industry and stakeholders, more environmental factors are involved in industry strategy with policy (industry policy and foreign investment policy), international cooperation(capital, technology and management, etc by multi-national companies and foreign direct investment), industrial foundation, market capacity, market demand, intensity of market competition and so on, which shaping external environment. The industrial internal environment is also influenced by natural condition, geographic position, source of raw material, public facility and the level of management and service ${ }^{[4]}$.

The environmental factors influencing the formation of industrial strategy are much more complex than those of enterprise strategy. Environmental analysis model is illustrated in the figure 2 .

Judging from the above analysis, industrial environment is the important external environment of enterprise strategy analysis, and in turn enterprises serve as the internal environment of industrial strategy analysis.

To sum up, the difference between the industrial strategy and enterprise strategy is displayed in the table 1 below.
Table 1 Difference between Industrial

Strategy and Enterprise Strategy

\begin{tabular}{|c|c|c|}
\hline Category & Enterprise Strategy & Industrial Strategy \\
\hline $\begin{array}{l}\text { Strategic } \\
\text { Level }\end{array}$ & Micro-level & Meso-level \\
\hline $\begin{array}{l}\text { Strategic } \\
\text { Subject }\end{array}$ & $\begin{array}{l}\text { enterprise, entrepreneur, } \\
\text { consulting agency, } \\
\text { expert }\end{array}$ & $\begin{array}{l}\text { state industrial depart- } \\
\text { ment, industrial associa- } \\
\text { tion, industry alliance, } \\
\text { consulting agency, } \\
\text { expert }\end{array}$ \\
\hline $\begin{array}{l}\text { Object of } \\
\text { Study }\end{array}$ & $\begin{array}{l}\text { focus on individual } \\
\text { problems of each enter- } \\
\text { prise with individualized } \\
\text { competition being the } \\
\text { analysis basis }\end{array}$ & $\begin{array}{l}\text { focus on the industry } \\
\text { with different laws and } \\
\text { disciplines as a whole }\end{array}$ \\
\hline $\begin{array}{l}\text { Research } \\
\text { Purpose }\end{array}$ & $\begin{array}{l}\text { acquire competitive } \\
\text { advantage, increase } \\
\text { profitability, sustain } \\
\text { long-term development } \\
\text { of enterprises }\end{array}$ & $\begin{array}{l}\text { identify the trend of } \\
\text { industrial changes, } \\
\text { features and laws and } \\
\text { disciplines; propose } \\
\text { reasonable and effective } \\
\text { measures; sharpen } \\
\text { competitive advantage, } \\
\text { gain advantage in core } \\
\text { technologies, and secure } \\
\text { the industrial leading } \\
\text { position domestically or } \\
\text { internationally }\end{array}$ \\
\hline $\begin{array}{l}\text { Research } \\
\text { Starting } \\
\text { Point }\end{array}$ & $\begin{array}{l}\text { starting from self- } \\
\text { interests of enterprises }\end{array}$ & $\begin{array}{l}\text { starting from the long- } \\
\text { term development of the } \\
\text { state and the industry }\end{array}$ \\
\hline \multirow[t]{2}{*}{$\begin{array}{l}\text { Environment } \\
\text { Factor }\end{array}$} & $\begin{array}{l}\text { External environment: } \\
\text { politics and law, econo- } \\
\text { my, population, society } \\
\text { and culture, science and } \\
\text { technology, industrial } \\
\text { structure, industrial } \\
\text { competitiveness and } \\
\text { attractiveness, enterprise } \\
\text { stakeholders, comple- } \\
\text { mentary products }\end{array}$ & $\begin{array}{l}\text { External environment: } \\
\text { politics and law, econo- } \\
\text { my, science and tech- } \\
\text { nology, society, culture, } \\
\text { population, stakeholders, } \\
\text { policy, international } \\
\text { cooperation, industrial } \\
\text { foundation, market } \\
\text { capacity, market de- } \\
\text { mand, intensity of mar- } \\
\text { ket competition, and } \\
\text { other complementary, } \\
\text { supporting and correlat- } \\
\text { ing industries }\end{array}$ \\
\hline & $\begin{array}{l}\text { Internal environment: } \\
\text { enterprise resources, } \\
\text { capability and core } \\
\text { competitiveness }\end{array}$ & $\begin{array}{l}\text { Internal environment: } \\
\text { industrial competitive- } \\
\text { ness, industrial structure, } \\
\text { natural conditions, } \\
\text { geographic position, } \\
\text { source of raw material, } \\
\text { public facility and the } \\
\text { level of management and } \\
\text { service }\end{array}$ \\
\hline
\end{tabular}

The most important element in the profitability of enterprises lies in the profitability of the industry. As market is always in an ever changing process, the industry is accordingly undergoing cyclical changes, thereby affecting the environment where enterprises survive and thrive and thus the profitability of enterprises.

In enterprise strategy management, the industrial environment where enterprises survive and thrive is of such critical significance to the competitiveness of enterprises as industrial strategy plays a deciding role in the enterprise strategy. At different phases of industrial development, enterprises tend to prefer different strate- 
gies $^{[5,6]}$. Not only is the industrial strategy of significance to industry itself, but also exerts certain influence on the development of enterprises.

\section{Conclusion}

Industrial strategy and enterprise strategy are of different strategic levels. They are complementing, influencing and mutually reinforcing each other. A clear line can be drawn between these two as the former studies on industrial development and the latter enterprise competitiveness. Only when the difference is better understood can we gain an insight into the study of industrial strategy. This holds practical importance for guiding the enterprise strategy management.

\section{References}

[1] Su Dongshui. Industrial Economics[M]. Beijing, HIGHER EDUCATION PRESS, 2000, PP.4-5

[2] Zhang Dongsheng, Li Yanshuang. Enterprise Strategy Management [M]. Beijing, China Machine Press, 2005, pp.81-88
[3] Michael E. Porter. The Competitive Advantage [M]. Beijing, Huaxia Publishing House, 1997, pp.4-10

[4] Michael E.Porter. The Competitive Advantage of Nations [M]. Beijing, CHINA CITIC PRESS, 2007, pp.64116

[5] Wang Qun, Zhang Yang, Zheng Sheng'an. Study on Factors in Formulating Enterprise Strategy from the Perspective of Industrial Lifecycle [J]. Economic Research, 2008, (5), pp.4852

[6] David Francas, Mirko Kremer, Stefan Minner, Markus Friese. Strategic process flexibility under lifecycle demand $[\mathrm{J}]$. International Journal of Production Economics, 2009, (2), pp.427-440

[7] Ville Isoherranen, Pekka Kess, Kongkiti Phusavat, Binshan Lin. Strategy changes analysis using life cycle framework and strategy typology [J]. International journal of management and enterprise Development, $2011,11(2 / 3 / 4)$

[8] Liu Jianguo. Industrial Market Environment Characteristic and Enterprise Strategy Risk [J]. Technoeconomics \&Management Research, 2010, (6), PP.79-82 